\title{
Reevaluation of the digestible lysine requirement for broilers based on genetic potential
}

\author{
Juliano Cesar De Paula Dorigam, Nilva Kazue Sakomura*, Luciano Hauschild, Edney Pereira da Silva, Hilda Cristina Palma \\ Bendezu, João Batista Kochenborger Fernandes
}

\author{
São Paulo State University - Dept. of Animal Sciences and \\ Nutrition, Via de Acesso Prof. Paulo Donato Castellane s/n - \\ 14884-900 - Jaboticabal - SP - Brazil. \\ *Corresponding author <sakomura@fcav.unesp.br>
}

Edited by: Concepta Margaret McManus Pimentel

\begin{abstract}
Broiler strains available in the poultry industry present different requirements for dietary lysine due to their different growth potentials as a result of their genetic makeup. This study aimed to determine the model parameters for maximum nitrogen retention $\left(\mathrm{NR}_{\max } \mathrm{T}\right)$, the nitrogen maintenance requirement (NMR) and the efficiency of lysine utilization $\left(b c^{-1}\right)$ to reevaluate the lysine (Lys) requirements of male and female broilers. Nitrogen balance trials were performed during three periods (I: 6-21 days, II: 22-37 days, and III: 38-53 days). Seven treatments were used for males and females; the treatments consisted of seven diets with protein levels ranging from 61 to $364 \mathrm{~g} \mathrm{~kg}^{-1}$ dry matter, with Lys being limiting in the dietary nitrogen (4.91 $\mathrm{g}$ of Lys in $16 \mathrm{~g}$ of $\mathrm{N}$ ). Nitrogen intake (NI), excretion (NEX), deposition (ND, ND=NI-NEX) and retention (NR, $\mathrm{NR}=\mathrm{ND}+\mathrm{NMR}$ ) values were obtained. The NMR was represented by the exponential relationship between NEX and NI. The $\mathrm{NR}_{\max } \mathrm{T}$ and $b c^{-1}$ were estimated by the exponential fit between ND and NI. The $\mathrm{NR}_{\max } \mathrm{T}, b c^{-1}$, and NMR values were combined in a model to estimate Lys intake by simulating different percentages of the $\mathrm{NR}_{\max } \mathrm{T}$. The Lys intake estimates were 581, 1,538, and 2,171 $\mathrm{mg}_{\text {day }}{ }^{-1}$ for males and 512, 1,340, and $1674 \mathrm{mg}$ day $^{-1}$ for females during periods I, II, and III, respectively. Due to the flexibility of the model, it is possible to calculate the Lys intake for percentages of NR in the range of practical performance data.

Keywords: amino acid, exponential model, maintenance, nitrogen retention, performance
\end{abstract}

broilers fed diets based on corn and soybean meal. For these reasons lysine was chosen as the reference amino acid as the ideal protein concept, in which all other essential amino acids are formulated into the diet as a ratio to lysine (Emmert and Baker, 1997). Consequently, obtaining an accurate and precise estimate of lysine requirements of broilers is highly desirable. In addition, formulating diets based on an ideal protein concept results in an efficient use of dietary protein by improving nitrogen utilization, resulting in minimal nitrogen excretion.

Responses to dietary lysine levels have been studied for decades and mathematical models have been developed to predict lysine requirements (Han and Baker, 1994; Samadi and Liebert, 2007; Samadi and Liebert, 2008; Goulart et al., 2008). However, the daily dietary lysine requirements have changed over the past few years because of the considerable influence of progress in genetics. Thus, this study aimed to reevaluate the digestible lysine requirements of male and female broilers based on their genetic potential.

\section{Materials and Methods} achieved. However, studies have demonstrated that the response of a group of birds to nutrient intake is curvilinear due to variability in maintenance and growth potential (Curnow, 1973).

Broilers with a high capacity for lean deposition require higher amounts of lysine to maximize both their performance and the protein deposition rate in the carcass. Lysine is considered to be the second most limiting amino acid after the sulfur-containing amino acids for

\section{Birds and housing}

The experiment was conducted in Jaboticabal, in the state of São Paulo, Brazil $\left(21^{\circ} 15^{\prime} 16^{\prime \prime}\right.$ S; $48^{\circ} 19^{\prime} 19^{\prime \prime}$ W, altitude $607 \mathrm{~m}$ ). Nitrogen balance trials were performed in three periods (I: 6-21 days, II: 22-37 days, and III: 38-53 days) using 84 Cobb500 genotype broilers in each period (42 males and 42 females). The birds were indi- 
vidually distributed in a completely randomized design with seven treatments composed of six males and six females per experimental unit. The experimental units consisted of metabolic cages with wire flooring equipped with individual feeders and water drinkers. This study was approved by the Ethics Committee on Animal Use (CEUA) of the Faculty of Agriculture and Veterinary Sciences, UNESP, Jaboticabal (protocol number 007125-08).

\section{Experimental diets}

The first six treatments consisted of varying levels of dietary protein at 61 (N1), 124 (N2), 183 (N3), 239 (N4), 295 (N5), and 364 (N6) g kg-1 of dry matter (DM); these treatments all maintained lysine as the first limiting amino acid (at $4.91 \mathrm{~g}$ of lysine for every $16 \mathrm{~g}$ of $\mathrm{N}$ ). The seventh treatment (N7) was obtained by adding $4 \mathrm{~g}$ of L-lysine $\mathrm{HCl}(78 \%)$ per $\mathrm{kg}$ of feed to a diet composition similar to that of $\mathrm{N} 1$ containing $61 \mathrm{~g} \mathrm{~kg}^{-1} \mathrm{DM}$ to verify that lysine was the first limiting amino acid in the diets. The experimental diets were obtained by diluting a high protein diet (consisting of soybean meal, corn gluten meal and crystalline amino acids) with a protein-free diet consisting mainly of corn starch (Table 1) to obtain the graded levels of dietary protein and to keep lysine as the first limiting amino acid in all diets (thereby maintaining the amino acid ratio). The composition of digestible amino acids analyzed in the experimental diets is presented in Table 2. The proportion of high protein diet (N6) to protein-free diet used in the preparation of the experimental diets was 15:85 for N1, 32:68 for N2, 49:51 for N3, 66:34 for N4, 83:17 for N5, and 100:0 for N6.

\section{Feeding and data collection}

The experimental period was divided into five days of adaptation to the diets followed by two consecutive periods of excreta collection (five days each); at the end of each period, nitrogen balance data were obtained from six different birds receiving the same diet. The experimental diets were provided ad libitum throughout the entire study period. During the collection periods,

Table 1 - Composition of experimental diets.

\begin{tabular}{|c|c|c|c|c|c|c|c|}
\hline \multirow{2}{*}{$\begin{array}{l}\text { Ingredients } \\
\left(\mathrm{g} \mathrm{kg}^{-1}\right)\end{array}$} & \multicolumn{7}{|c|}{ Diets } \\
\hline & \multicolumn{3}{|c|}{ High protein (N6) } & \multicolumn{4}{|c|}{ Protein-free } \\
\hline Soybean meal (45 \%) & \multicolumn{3}{|c|}{540.3} & \multicolumn{4}{|c|}{-} \\
\hline Corn & \multicolumn{3}{|c|}{170.0} & \multicolumn{4}{|c|}{ - } \\
\hline Corn gluten meal (60 \%) & \multicolumn{3}{|c|}{165.0} & \multicolumn{4}{|c|}{-} \\
\hline Soybean oil & \multicolumn{3}{|c|}{80.7} & \multicolumn{4}{|c|}{65.0} \\
\hline Dicalcium phosphate & \multicolumn{3}{|c|}{19.0} & \multicolumn{4}{|c|}{27.0} \\
\hline Limestone & \multicolumn{3}{|c|}{7.2} & \multicolumn{4}{|c|}{3.4} \\
\hline Salt & \multicolumn{3}{|c|}{5.1} & \multicolumn{4}{|c|}{5.2} \\
\hline DL-Methionine (99 \%) & \multicolumn{3}{|c|}{4.5} & \multicolumn{4}{|c|}{-} \\
\hline L-Lysine HCl (78 \%) & \multicolumn{3}{|c|}{3.5} & \multicolumn{4}{|c|}{-} \\
\hline L-Threonine (99 \%) & \multicolumn{3}{|c|}{1.5} & \multicolumn{4}{|c|}{-} \\
\hline Vitaminic supplement ${ }^{1}$ & \multicolumn{3}{|c|}{1.0} & \multicolumn{4}{|c|}{1.0} \\
\hline Choline chloride (70 \%) & \multicolumn{3}{|c|}{0.7} & \multicolumn{4}{|c|}{0.7} \\
\hline Mineral supplement ${ }^{2}$ & \multicolumn{3}{|c|}{1.0} & \multicolumn{4}{|c|}{1.0} \\
\hline Anticoccidial ${ }^{3}$ & & & & & & & \\
\hline Potassium chloride & & & & & & & \\
\hline Corn starch & & & & & & & \\
\hline Inert (sand) & & & & & & & \\
\hline Rice husk & & & & & & & \\
\hline Sugar & & & & & & & \\
\hline Nutritional comnosition ( $\left.\sigma \mathrm{kg}^{-1} \mathrm{DM}\right){ }^{4}$ & & & & Diet & & & \\
\hline Tvutritional composition (g $\left.\mathrm{kg}^{-1} \mathrm{DVIV}\right)^{4}$ & N1 & N2 & N3 & N4 & N5 & N6 & N7 \\
\hline Crude protein & 61.0 & 124.0 & 183.0 & 239.0 & 295.0 & 364.0 & 61.0 \\
\hline Ether extract & 72.1 & 89.1 & 83.2 & 88.7 & 94.3 & 99.8 & 72.1 \\
\hline Crude fiber & 48.4 & 45.5 & 42.6 & 39.7 & 36.8 & 33.9 & 48.4 \\
\hline Calcium & 9.3 & 9.3 & 9.3 & 9.3 & 9.3 & 9.3 & 9.3 \\
\hline Sodium & 2.2 & 2.2 & 2.2 & 2.2 & 2.2 & 2.2 & 2.2 \\
\hline Potassium & 6.6 & 7.4 & 8.2 & 9.0 & 9.8 & 10.6 & 6.6 \\
\hline Available phosphorus & 4.7 & 4.7 & 4.7 & 4.7 & 4.7 & 4.7 & 4.7 \\
\hline $\mathrm{AME}_{n}\left(\mathrm{Mcal} \mathrm{kg}^{-1}\right)^{5}$ & 3.15 & 3.15 & 3.15 & 3.15 & 3.15 & 3.15 & 3.15 \\
\hline
\end{tabular}


Table 2 - Digestible amino acid content of experimental diets.

\begin{tabular}{|c|c|c|c|c|c|c|c|c|}
\hline Amino acids $(A A)^{1}$ & N1 & $\mathrm{N} 2$ & N3 & N4 & N5 & N6 & N7 & AA-Ratio (AA/lysine) \\
\hline Lysine & 4.53 & 4.74 & 4.92 & 5.07 & 5.16 & 5.04 & $9.43(100)^{2}$ & 100 \\
\hline Arginine & 5.18 & 5.43 & 5.63 & 5.80 & 5.90 & 5.77 & $4.87(52)$ & 114 \\
\hline Histidine & 2.07 & 2.17 & 2.25 & 2.32 & 2.36 & 2.31 & $1.95(21)$ & 46 \\
\hline Isoleucine & 3.64 & 3.82 & 3.96 & 4.08 & 4.15 & 4.06 & $3.42(36)$ & 81 \\
\hline Leucine & 8.84 & 9.27 & 9.61 & 9.90 & 10.07 & 9.84 & $8.30(88)$ & 195 \\
\hline Met+Cys & 3.65 & 3.83 & 3.97 & 4.09 & 4.16 & 4.07 & $3.43(36)$ & 81 \\
\hline Methionine & 2.50 & 2.63 & 2.72 & 2.80 & 2.85 & 2.79 & $2.35(25)$ & 55 \\
\hline Threonine & 3.36 & 3.52 & 3.65 & 3.76 & 3.82 & 3.73 & $3.15(33)$ & 74 \\
\hline Tryptophan & 0.88 & 0.92 & 0.96 & 0.99 & 1.00 & 0.98 & $0.83(9)$ & 19 \\
\hline Valine & 3.83 & 4.01 & 4.16 & 4.29 & 4.36 & 4.26 & $3.60(38)$ & 85 \\
\hline
\end{tabular}

${ }^{1}$ Analyzed composition of the amino acids in experimental diets ( $\mathrm{g}$ of $\mathrm{AA}$ in $16 \mathrm{~g}$ of N); ${ }^{2} \mathrm{AA}$ ratio in counter-proof diet.

the excreta were collected in trays (free from feathers) and weighed at the end of each period.

\section{Chemical analysis}

The samples of excreta obtained from each experimental unit during each period were thawed, homogenized, weighed in Petri dishes and frozen again. Afterwards, the excreta samples were freeze-dried for $72 \mathrm{~h}$ at $-80{ }^{\circ} \mathrm{C}$ and $0.08 \mathrm{MPa}$ of pressure. The samples were weighed to quantify the dry matter content and were then ground in a Micro Mill. The total nitrogen contents of the diets and excreta were analyzed in a nitrogen distiller using the Kjeldahl method (Method No. 2001.11) according to AOAC (2005). A factor of 6.25 was used in the conversion of the nitrogen value to crude protein (CP). The total amino acid content of the ingredients in the experimental diets was analyzed using high performance liquid chromatography (HPLC), and these values were corrected for digestible amino acids using the tabulated coefficients of digestibility (Rostagno et al., 2011).

\section{Statistical analysis}

Data were analyzed by a one-way ANOVA using a GLM procedure and were fitted to exponential models using PROC NLIN in SAS (Statistical Analysis System, version 9.1); the Levenberg-Marquardt algorithm was used to converge on a solution for these models.

Regression analysis between nitrogen intake (NI, $\mathrm{mg} \mathrm{BW}^{0.67} \mathrm{~kg}^{-1}$ day $^{-1}$ ) and nitrogen excretion (NEX, mg $\mathrm{BW}^{0.67} \mathrm{~kg}^{-1} \mathrm{day}^{-1}$ ) was used in the fitting of the exponential function:

$\mathrm{NEX}=\mathrm{NMR} \times e^{b \times \mathrm{NI}}$

where NMR is the nitrogen requirement for maintenance $\left(\mathrm{mg} \mathrm{BW} \mathrm{BW}^{0.67} \mathrm{~kg}^{-1} \mathrm{day}^{-1}\right), \quad b$ is the slope of the exponential curve and $e$ is the base number of the natural logarithm $(\ln )$. From the exponential function (1), the NMR was estimated by considering the intercept of the curve on the $\mathrm{y}$-axis $(\mathrm{NEX})$ when $\mathrm{NI}=0$. The nitrogen balance or nitrogen deposition (ND, mg BW ${ }^{0.67} \mathrm{~kg}^{-1}$ day $^{-1}$ ) was calculated as the difference between NI and NEX (ND= NI-NEX).
Regression analysis between NI and nitrogen retention $\left(\mathrm{NR}=\mathrm{ND}+\mathrm{NMR}, \mathrm{mg} \mathrm{BW}^{0.67} \mathrm{~kg}^{-1} \mathrm{day}^{-1}\right)$ was performed to fit another exponential model:

$\mathrm{NR}=\mathrm{NR}_{\max } \mathrm{T} \times\left(1-e^{-b \times \mathrm{NI}}\right)$

where $\mathrm{NR}_{\max } \mathrm{T}$ is the theoretical maximum nitrogen retention $\left(\mathrm{mg} \mathrm{BW}^{0.67} \mathrm{~kg}^{-1} \mathrm{day}^{-1}\right)$. Another way to express the exponential model (2), according to Samadi and Liebert (2007), is by regression analysis between NI and ND, considering ND = NR-NMR, as shown here:

$\mathrm{ND}=\mathrm{NR}_{\max } \mathrm{T} \times\left(1-e^{-b \times \mathrm{NI}}\right)-\mathrm{NMR}$

The model generated in equation (3) was used to estimate $\mathrm{NR}_{\max } \mathrm{T}$ for each age, where $b$ is the slope of the nitrogen retention curve and $e$ is the base number of the natural logarithm $(I n)$. The $\mathrm{NR}_{\max } \mathrm{T}$ was estimated by a statistical procedure following several iterations by the Levenberg-Marquardt algorithm until the sum of the squares of the residual was minimized. The theoretical maximum nitrogen deposition $\left(\mathrm{ND}_{\max } \mathrm{T}, \mathrm{mg} \mathrm{BW}^{0.67} \mathrm{~kg}^{-1}\right.$ day $^{-1}$ ) for each period was obtained by subtracting the NMR from the $\mathrm{NR}_{\max } \mathrm{T}\left(\mathrm{ND}_{\max } \mathrm{T}=\mathrm{NR}_{\max } \mathrm{T}-\mathrm{NMR}\right)$ expression.

To estimate digestible lysine requirements, the first step was to modify equation (2) by logarithmization and by several conversions, the $b$ parameter, used as feed protein evaluation, can be calculated by following the equation proposed by Samadi and Liebert (2007):

$\mathrm{b}=\left[\ln \mathrm{NR}_{\max } \mathrm{T}-\ln \left(\mathrm{NR}_{\max } \mathrm{T}-\mathrm{NR}\right)\right] / \mathrm{NI}$

The $b$ value $\left(\times 10^{-6}\right)$ calculated in this way and divided by the concentration of the limiting amino acid in the feed protein, $c$ (g of AA in $16 \mathrm{~g}$ of N), was used to express the efficiency of utilization of the limiting amino acid $\left(b c^{-1}\right)$. The $b c^{-1}$ value $\left(\times 10^{-6}\right)$ is represented by the slope of the straight line between the quality of the protein in the diet $(b)$ and the limiting amino acid (LAA) concentration $(c)$ in the diet provided. 
The necessary NI for a defined level of NR, depending on the parameter $b$ (feed protein quality), can be calculated from a modification of the following equation (4):

$\mathrm{NI}=\left[\ln \mathrm{NR}_{\max } \mathrm{T}-\ln \left(\mathrm{NR}_{\max } \mathrm{T}-\mathrm{NR}\right)\right] / b$

According to Samadi and Liebert (2008), the mathematical description of NI against limiting amino acid intake (LAAI) is calculated as:

$\mathrm{NI}=16 \mathrm{LAAI} / \mathrm{c}$

The LAAI was obtained by replacing NI in equation (5) with equation (6), resulting in equation (7):

$\mathrm{LAAI}=\left[\ln \mathrm{NR}_{\max } \mathrm{T}-\ln \left(\mathrm{NR}_{\max } \mathrm{T}-\mathrm{NR}\right)\right] / 16 b c^{-1}$

where LAAI is the intake of the LAA and $b c^{-1}$ is the efficiency of utilization of the dietary LAA. The LAAI equation (7) was used to calculate the Lys requirement (mg day $^{-1}$ ) based on estimated NR data (targeted growth performance) and $b c^{-1}$. The NR was expressed as a percentage of the $\mathrm{NR}_{\max } \mathrm{T}$ using mean values for body weights $(\mathrm{BW}, \mathrm{g})$, feed intake $\left(\mathrm{FI}, \mathrm{g}^{-1 a y^{-1}}\right)$ and Lys requirements (g $\mathrm{kg}^{-1}$ ) from the Cobb500 management guide (Cobb, 2008; 2012 ) to simulate targeted growth performance recommended under practical conditions. For this simulation, the Lys requirement $\left(\mathrm{mg} \mathrm{day}^{-1}\right)$ was expressed per mass of metabolic BW (mg BW $\left.{ }^{0.67} \mathrm{~kg}^{-1} \mathrm{day}^{-1}\right)$ using a mathematical rearrangement of equation (7), where the LAAI (in this case Lys) was multiplied by $16 b c^{-1}$ resulting in the following equation (7a):

$16 \times \mathrm{Lys} \times b c^{-1}=\ln \left(\mathrm{NR}_{\max } \mathrm{T}\right)-\ln \left(\mathrm{NR}_{\max } \mathrm{T}-\mathrm{NR}\right)$

Isolating $\ln \left(\mathrm{NR}_{\max } \mathrm{T}-\mathrm{NR}\right)$ in equation (7a) results in equation $(7 \mathrm{~b})$ :

$\ln \left(\mathrm{NR}_{\max } \mathrm{T}-\mathrm{NR}\right)=\ln \left(\mathrm{NR}_{\max } \mathrm{T}\right)-\left(16 \times \mathrm{Lys} \times b c^{-1}\right)$

The $\ln (\mathrm{x})=\mathrm{y}$ function can be interpreted using the usual properties for inverse functions, that is $x=e^{(y)}$. Considering that $\mathrm{x}=\mathrm{NR}_{\max } \mathrm{T}-\mathrm{NR}$ and $\mathrm{y}=\ln \left(\mathrm{NR}_{\max } \mathrm{T}\right)$ $\left(16 \times\right.$ Lys $\left.\times b^{-1}\right)$, it is possible to derive the following equation $(7 \mathrm{c})$ :

$\mathrm{NR}_{\max } \mathrm{T}-\mathrm{NR}=e^{\left(\ln (\mathrm{NRm} \operatorname{maxT})-\left(16 \times \mathrm{Ly} s \times b c^{-1}\right) \mid\right.}$

Finally, taking NR as the response in equation $(7 \mathrm{c})$ results in equation (8):

$\mathrm{NR}=\mathrm{NR}_{\max } \mathrm{T}-e^{(l n \mid \mathrm{NRmaxT})-\left(16 \times \mathrm{Ly} s \times b c^{-1}\right) \mid}$

From equation (8), the NR expressed as a percentage of the $\mathrm{NR}_{\max } \mathrm{T}$ (the reference for genetic growth potential) was calculated using the $\mathrm{NR}_{\max } \mathrm{T}$ and $b c^{-1}$ values estimated in this study to model the Lys data and de- termine the Lys requirement nearest to the growth potential observed under practical conditions. The optimal Lys concentration in the diet $\left(\mathrm{g} \mathrm{kg}^{-1}\right)$ was calculated from the assumptions made for the daily feed intake $( \pm 10 \mathrm{~g})$ taken from the management guide for the lineage $(\mathrm{Cobb}$, $2008 ; 2012$ ). The optimum level of dietary lysine was calculated as the Lys requirement $\left(\mathrm{g} \mathrm{day}^{-1}\right)$ divided by the feed intake $\left(\mathrm{kg} \mathrm{day}^{-1}\right)$.

\section{Results}

The ND data responded $(p<0.001)$ because of the graded dietary protein supply from N1 to N6 (Table 3 and 4). Accordingly, the NEincreased $(p<0.001)$ with increasing NI and mostly exceeded the ND data observed. An increase in the ND response of birds was observed in the counter-proof treatment (N7), and this response was between the values obtained from $\mathrm{N} 1$ and $\mathrm{N} 2$, confirming that lysine was the first limiting amino acid in the experimental diets.

The NMR values obtained in this study increased from $219 \mathrm{mg} \mathrm{BW}^{0.67} \mathrm{~kg}^{-1}$ day ${ }^{-1}$ (Period I) to $276 \mathrm{mg} \mathrm{BW}^{0.67}$ $\mathrm{kg}^{-1}$ day $^{-1}$ (period III) and from $225 \mathrm{mg} \mathrm{BW}^{0.67} \mathrm{~kg}^{-1}$ day $^{-1}$ (Period I) to $271 \mathrm{mg} \mathrm{BW}{ }^{0.67} \mathrm{~kg}^{-1}$ day ${ }^{-1}$ (period III) for males and females, respectively (Figure 1).
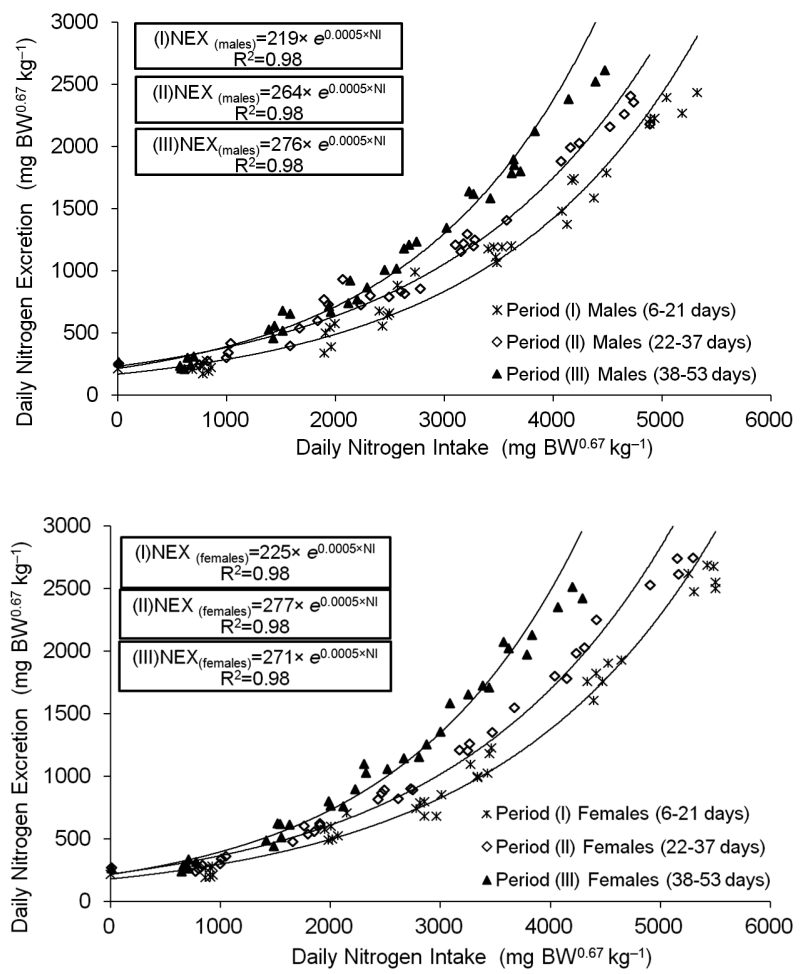

Figure 1 - Estimation of the nitrogen requirements for maintenance (NMR) by fitting an exponential function between the daily nitrogen intake (NI) and the daily nitrogen excreted (NEX) during a gradual increase in supplied protein for Cobb500 males and females. $e=$ base of the natural logarithm (In). 
The estimated values of the $\mathrm{ND}_{\max } \mathrm{T}$ decreased, depending on age, from $3,746 \mathrm{mg} \mathrm{BW}{ }^{0.67} \mathrm{~kg}^{-1}$ day $^{-1}$ (period I) to $2,204 \mathrm{mg} \mathrm{BW}^{0.67} \mathrm{~kg}^{-1}$ day $^{-1}$ (period III) for males and from $3,620 \mathrm{mg} \mathrm{BW}{ }^{0.67} \mathrm{~kg}^{-1}$ day $^{-1}$ (period I) to 2,048 mg BW ${ }^{0.67} \mathrm{~kg}^{-1}$ day ${ }^{-1}$ (period III) for females (Figure 2). In contrast, the $b$ parameter calculated by equation (4) increased with age and was 286,322 , and $466 \times 10^{-6}$ for males and 305,346 , and $507 \times 10^{-6}$ for females during pe-

Table 3 - Mean body weight (BW), dry matter intake (DMI), daily nitrogen intake (NI), daily nitrogen excretion (NEX) and daily nitrogen deposition (ND) obtained in nitrogen balance trials with males receiving graded levels of protein ${ }^{1}$.

\begin{tabular}{|c|c|c|c|c|c|c|c|c|c|}
\hline \multirow{3}{*}{ Diets } & \multicolumn{6}{|c|}{ Males } & & \multirow[b]{3}{*}{$\mathrm{RSD}^{3}$} & \multirow[b]{3}{*}{$\mathrm{p}$-value } \\
\hline & \multicolumn{7}{|c|}{ Period I (6-21 days) ${ }^{2}$} & & \\
\hline & N1 & N2 & N3 & N4 & N5 & N6 & N7 & & \\
\hline BW (g) & 261 & 348 & 381 & 405 & 402 & 417 & 254 & 140 & NS \\
\hline DMI $\left(\right.$ g day $\left.^{-1}\right)$ & 32 & 48 & 45 & 49 & 48 & 47 & 40 & 12 & NS \\
\hline $\mathrm{NI}\left(\mathrm{mg} \mathrm{BW}^{0.67} \mathrm{~kg}^{-1}\right)$ & 787 & 1941 & 2518 & 3493 & 4238 & 5043 & 1226 & 112 & *** \\
\hline $\mathrm{NEX}\left(\mathrm{mg} \mathrm{BW}^{0.67} \mathrm{~kg}^{-1}\right)$ & 225 & 475 & 741 & 1163 & 1622 & 2294 & 335 & 113 & $* * *$ \\
\hline $\mathrm{ND}\left(\mathrm{mg} B W^{0.67} \mathrm{~kg}^{-1}\right)$ & 562 & 1466 & 1777 & 2330 & 2616 & 2750 & 891 & 93 & *** \\
\hline \multirow{2}{*}{ Diets } & \multicolumn{7}{|c|}{ Period II (22-37 days) ${ }^{2}$} & & \\
\hline & N1 & $\mathrm{N} 2$ & N3 & N4 & N5 & N6 & N7 & $\mathrm{RSD}^{3}$ & $\mathrm{p}$-value \\
\hline BW (g) & 1211 & 1381 & 1490 & 1579 & 1420 & 1533 & 1201 & 269 & NS \\
\hline DMI $\left(\right.$ g day $\left.^{-1}\right)$ & 105 & 113 & 111 & 113 & 106 & 106 & 114 & 11 & NS \\
\hline $\mathrm{Nl}\left(\mathrm{mg} B W^{0.67} \mathrm{~kg}^{-1}\right)$ & 918 & 1826 & 2503 & 3193 & 4006 & 4652 & 1265 & 169 & *** \\
\hline NEX (mg BW0.67 kg-1) & 324 & 669 & 812 & 1229 & 1834 & 2303 & 512 & 133 & $* * *$ \\
\hline $\mathrm{ND}\left(\mathrm{mg} \mathrm{BW}^{0.67} \mathrm{~kg}^{-1}\right)$ & 594 & 1157 & 1691 & 1964 & 2172 & 2349 & 753 & 87 & $* * *$ \\
\hline \multirow{2}{*}{ Diets } & \multicolumn{7}{|c|}{ Period III (38-53 days) $)^{2}$} & & \\
\hline & N1 & N2 & N3 & N4 & N5 & N6 & N7 & $\mathrm{RSD}^{3}$ & $\mathrm{p}$-value \\
\hline BW (g) & 2902 & 3039 & 3166 & 3249 & 3198 & 3103 & 2874 & 267 & NS \\
\hline DMI $\left(\right.$ g day $\left.^{-1}\right)$ & 131 & 156 & 155 & 150 & 155 & 147 & 133 & 9 & ** \\
\hline $\mathrm{Nl}\left(\mathrm{mg} B W^{0.67} \mathrm{~kg}^{-1}\right)$ & 625 & 1474 & 2102 & 2607 & 3363 & 4024 & 811 & 182 & $\star * *$ \\
\hline NEX (mg BW0.67 kg-1) & 261 & 575 & 789 & 1139 & 1647 & 2232 & 285 & 159 & $\star * *$ \\
\hline $\mathrm{ND}\left(\mathrm{mg} \mathrm{BW}^{0.67} \mathrm{~kg}^{-1}\right)$ & 364 & 898 & 1312 & 1468 & 1716 & 1792 & 526 & 72 & $* * *$ \\
\hline
\end{tabular}

${ }^{1} \mathrm{~N} 1=61, \mathrm{~N} 2=124, \mathrm{~N} 3=183, \mathrm{~N} 4=239, \mathrm{~N} 5=295, \mathrm{~N} 6=364 \mathrm{~g} \mathrm{~kg}^{-1}$ dry matter and N7 is the counter-proof treatment (N1 + $4 \mathrm{~g}$ of L-lysine $\mathrm{HCl}(78 \%)$ per $\mathrm{kg}$ of feed); ${ }^{2}$ Mean value of two collection periods; ${ }^{3}$ Residual standard deviation, expressed in the same units as the related variable; NS, not significant; ${ }^{* *} p<0.05$; ${ }^{* \star *} p<$ 0.001 .

Table 4 - Mean body weight (BW), dry matter intake (DMI), daily nitrogen intake (NI), daily nitrogen excretion (NEX) and daily nitrogen deposition (ND) obtained in nitrogen balance trials with females receiving graded levels of protein ${ }^{1}$.

\begin{tabular}{|c|c|c|c|c|c|c|c|c|c|}
\hline \multirow{3}{*}{ Diets } & \multicolumn{7}{|c|}{ Females } & \multirow[b]{3}{*}{$\mathrm{RSD}^{3}$} & \multirow[b]{3}{*}{ p-value } \\
\hline & \multicolumn{7}{|c|}{ Period I (6-21 days) ${ }^{2}$} & & \\
\hline & N1 & N2 & N3 & N4 & N5 & N6 & N7 & & \\
\hline BW (g) & 254 & 312 & 342 & 373 & 383 & 363 & 270 & 122 & NS \\
\hline DMI (g day $\left.{ }^{-1}\right)$ & 36 & 46 & 47 & 45 & 49 & 47 & 40 & 11 & NS \\
\hline $\mathrm{NI}\left(\mathrm{mg} B W^{0.67} \mathrm{~kg}^{-1}\right)$ & 895 & 2025 & 2876 & 3379 & 4461 & 5409 & 1210 & 80 & *** \\
\hline NEX (mg BW ${ }^{0.67} \mathrm{~kg}^{-1}$ ) & 241 & 573 & 763 & 1092 & 1801 & 2591 & 360 & 83 & *** \\
\hline $\mathrm{ND}\left(\mathrm{mg} B W^{0.67} \mathrm{~kg}^{-1}\right)$ & 654 & 1452 & 2113 & 2286 & 2660 & 2818 & 850 & 87 & $* * *$ \\
\hline \multirow{2}{*}{, } & \multicolumn{7}{|c|}{ Period II (22-37 days) $)^{2}$} & & \\
\hline & $\mathrm{N} 1$ & N2 & N3 & N4 & N5 & N6 & N7 & $\mathrm{RSD}^{3}$ & $\mathrm{p}$-value \\
\hline BW (g) & 1192 & 1314 & 1398 & 1491 & 1381 & 1437 & 1235 & 210 & NS \\
\hline DMI (g day $\left.{ }^{-1}\right)$ & 103 & 109 & 109 & 112 & 108 & 112 & 106 & 8 & NS \\
\hline $\mathrm{NI}\left(\mathrm{mg} \mathrm{BW}{ }^{0.67} \mathrm{~kg}^{-1}\right)$ & 903 & 1806 & 2573 & 3282 & 4129 & 5121 & 1150 & 155 & *** \\
\hline NEX (mg BW0.67 $\mathrm{kg}^{-1}$ ) & 304 & 574 & 871 & 1261 & 1903 & 2661 & 347 & 113 & *** \\
\hline $\mathrm{ND}\left(\mathrm{mg} \mathrm{BW}^{0.67} \mathrm{~kg}^{-1}\right)$ & 599 & 1232 & 1703 & 2021 & 2225 & 2460 & 803 & 85 & $* * *$ \\
\hline \multirow{2}{*}{ 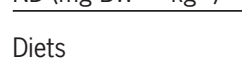 } & \multicolumn{7}{|c|}{ Period III (38-53 days) ${ }^{2}$} & & \\
\hline & N1 & $\mathrm{N} 2$ & N3 & N4 & N5 & N6 & N7 & $\mathrm{RSD}^{3}$ & $\mathrm{p}$-value \\
\hline BW (g) & 2270 & 2427 & 2589 & 2530 & 2530 & 2600 & 2342 & 238 & NS \\
\hline DMI (g day ${ }^{-1}$ ) & 123 & 138 & 139 & 137 & 138 & 133 & 146 & 10 & $* *$ \\
\hline $\mathrm{NI}\left(\mathrm{mg} \mathrm{BW}^{0.67} \mathrm{~kg}^{-1}\right)$ & 693 & 1517 & 2153 & 2819 & 3510 & 4080 & 1023 & 151 & $* * *$ \\
\hline NEX (mg BW ${ }^{0.67} \mathrm{~kg}^{-1}$ ) & 292 & 554 & 897 & 1264 & 1890 & 2319 & 311 & 147 & $\star \star \star *$ \\
\hline $\mathrm{ND}\left(\mathrm{mg} B W^{0.67} \mathrm{~kg}^{-1}\right)$ & 402 & 963 & 1255 & 1555 & 1620 & 1761 & 712 & 70 & $* * *$ \\
\hline
\end{tabular}

${ }^{1} \mathrm{~N} 1=61, \mathrm{~N} 2=124, \mathrm{~N} 3=183, \mathrm{~N} 4=239, \mathrm{~N} 5=295, \mathrm{~N} 6=364 \mathrm{~g} \mathrm{~kg}^{-1}$ dry matter and $\mathrm{N} 7$ is the counter-proof treatment ( $\mathrm{N} 1+4 \mathrm{~g}$ of L-lysine $\mathrm{HCl}(78 \%$ ) per kg of feed); ${ }^{2}$ Mean value of two collection periods; ${ }^{3}$ Residual standard deviation, expressed in the same units as the related variable; NS, not significant; ${ }^{* *} p<0.05$; ${ }^{\star * *} p<$ 0.001 . 

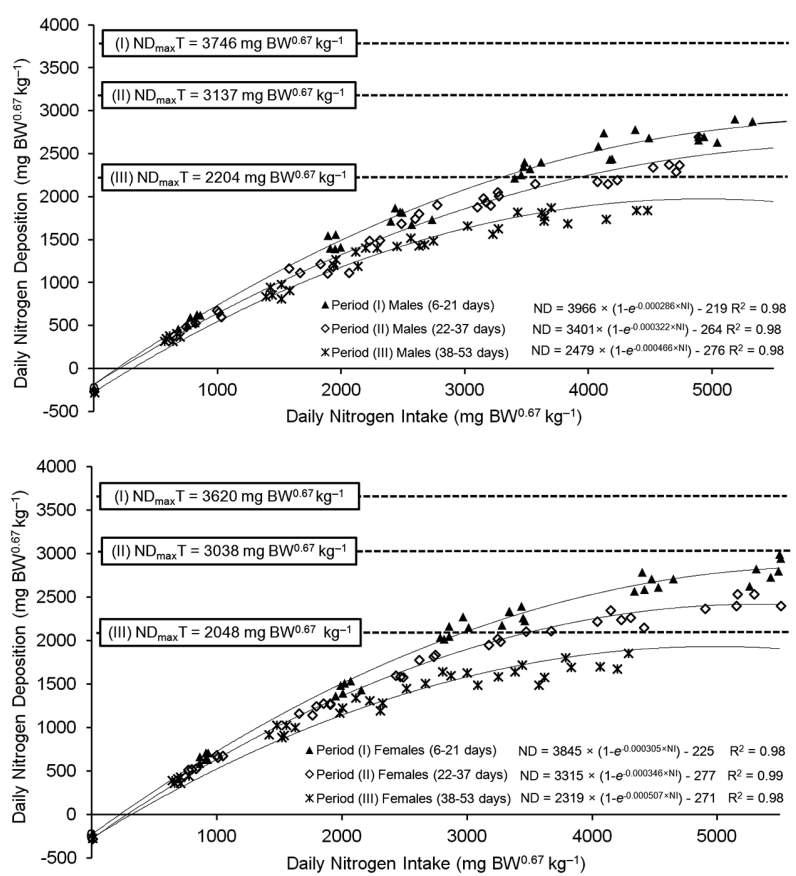

Figure 2 - Estimation of the theoretical potential for nitrogen deposition $\left(\mathrm{ND}_{\max } \mathrm{T}\right)$ in male and female broilers of the Cobb500 genotype based on the ratio between the daily nitrogen intake (NI) and the daily nitrogen balance (ND) at different ages.

riods I, II, and III, respectively. This increase in the $b$ value was accompanied by a decline in the $\mathrm{ND}_{\max } \mathrm{T}$ value that can be observed in Figure 2 and is characteristic of the modeling procedure. Consequently, the efficiency of lysine utilization, $b c^{-1}$, also increased. The mean values for the ratio between the $b$ parameter and the lysine concentration, $c$, (from Table 2) were estimated at 58, 66 , and $96 \times 10^{-6}$ for males and 62,71 , and $104 \times 10^{-6}$ for females during periods I, II, and III, respectively.

Results of the simulation using equation (8) and data from the Cobb500 management guides to estimate the NR under practical conditions are summarized in Table 5. The simulation showed that the potentials for nitrogen retention (NR) using the 2008 recommendations are 64 and $65 \%$ of the $\mathrm{NR}_{\max } \mathrm{T}$ (period I), 71 and $73 \%$ of the $\mathrm{NR}_{\max } \mathrm{T}$ (Period II), and 75 and $77 \%$ of the $\mathrm{NR}_{\max } \mathrm{T}$ (Period III) for males and females, respectively. For the 2012 management guide recommendations, the estimated potentials for the birds were $65 \%$ of the $\mathrm{NR}_{\max } \mathrm{T}$ for both sexes (period I), 72 and $71 \%$ of the $\mathrm{NR}_{\max } \mathrm{T}$ (period II), and 79 and $78 \%$ of the $\mathrm{NR}_{\max } \mathrm{T}$ (period III) for males and females, respectively. The difference in the potentials from 2008 to 2012 represented approximately 1 to $4 \%$ for males but no more than 1 $\%$ for females.

Results for modeling of the Lys requirement data from equation (7) are summarized in Table 6 and demonstrate the application of the modeling procedure to establish Lys requirement data $\left(\mathrm{mg} \mathrm{day}^{-1}\right)$ from the tar-
Table 5 - Comparison between the nitrogen retention (NR) estimated in relation to the theoretical maximum nitrogen retention $\left(\mathrm{NR}_{\max } \mathrm{T}\right)^{1}$ using the body weights (BW), feed intake (FI) and lysine requirements (Lys) provided by the management guide for Cobb500 broilers.

\begin{tabular}{|c|c|c|c|c|c|c|}
\hline Period & BW & $\mathrm{FI}$ & Lys & Lys & $\mathrm{NR}^{3}$ & NR \\
\hline days & g & $\mathrm{g}$ day $^{-1}$ & \multicolumn{3}{|c|}{$\begin{array}{l}\text { Cobb } 2008 \\
\text { Males }\end{array}$} & $\left(\% \mathrm{NR}_{\max } \mathrm{T}\right)$ \\
\hline 6 to 21 & 501 & 65 & 10.1 & 1090 & 2522 & 64 \\
\hline 22 to 37 & 1633 & 168 & 9.5 & 1164 & 2405 & 71 \\
\hline 38 to 53 & \multicolumn{6}{|c|}{ Females } \\
\hline 6 to 21 & 457 & 63 & 10.1 & 1070 & 2511 & 65 \\
\hline 22 to 37 & 1442 & 153 & 9.5 & 1150 & 2417 & 73 \\
\hline 38 to 53 & 2633 & 186 & 9.2 & 896 & 1791 & 77 \\
\hline \multicolumn{7}{|c|}{ Cobb 2012} \\
\hline 6 to 21 & 510 & 65 & 10.8 & 1143 & 2589 & 65 \\
\hline 22 to 37 & 1583 & 173 & 9.6 & 1218 & 2461 & 72 \\
\hline 38 to 53 & 3047 & 235 & 9.2 & 1028 & 1964 & 79 \\
\hline \multicolumn{7}{|c|}{ Females } \\
\hline 6 to 21 & 488 & 61 & 10.8 & 1064 & 2506 & 65 \\
\hline 22 to 37 & 1474 & 148 & 9.6 & 1093 & 2356 & 71 \\
\hline 38 to 53 & 2795 & 198 & 9.2 & 920 & 1814 & 78 \\
\hline
\end{tabular}

${ }^{1} \mathrm{NR}_{\max } \mathrm{T}=3,966$ and 3,845 (6 to 21 days); 3,401 and 3,315 (22 to 37 days); and 2,479 and 2,319 mg BW0.67 $\mathrm{kg}^{-1}$ day $^{-1}$ (38 to 53 days) for males and females, respectively; ${ }^{2} \mathrm{bc}^{-1}=0.000058$ and 0.000062 ( 6 to 21 days); 0.000066 and 0.000071 (22 to 37 days); and 0.000096 and 0.000104 (38 to 53 days) for males and females, respectively; ${ }^{3} \mathrm{NR}=\mathrm{NR}_{\max } \mathrm{T}$ - $e^{(\ln (\mathrm{NR} \max T)}$

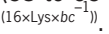

geted growth potential or nitrogen retention $(\mathrm{NR}, \mathrm{mg}$ $\mathrm{BW}^{0.67} \mathrm{~kg}^{-1}$ day $^{-1}$ ) and $b c^{-1}$.

Based on the calculated values for $b c^{-1}$, the Lys intake required to achieve $65 \%$ of the $\mathrm{NR}_{\max } \mathrm{T}$ for both sexes (estimated from the simulation in Table 5) during period I was estimated to be $581 \mathrm{mg} \mathrm{day}^{-1}$ for males and $512 \mathrm{mg}$ day $^{-1}$ for females. During period II, the Lys intake to achieve $72 \%$ of the $\mathrm{NR}_{\max } \mathrm{T}$ for males and $71 \%$ of the $\mathrm{NR}_{\max } \mathrm{T}$ for females was estimated to be $1,538 \mathrm{mg}$ day $^{-1}$ for males and 1,340 $\mathrm{mg} \mathrm{day}^{-1}$ for females. During period III, the Lys intake was estimated to be $2,171 \mathrm{mg}$ day $^{-1}$ for males and $1,674 \mathrm{mg}$ day $^{-1}$ for females to reach 79 and $78 \%$ of the $\mathrm{NR}_{\max } \mathrm{T}$, respectively.

\section{Discussion}

Dose response studies are generally based on the acceptance of a relationship between the content of the limiting amino acid in the diet and the growth response, but this ratio is only valid for the limiting position of the amino acid (Samadi and Liebert, 2006). By adding a small quantity of crystalline lysine in the N1 diet, it was possible to confirm that the amino acid tested in this study was in the limiting position because of the small incremental response in the birds being fed the N7 diet (Tables 3 and 4). This procedure was carried out to demonstrate that the response obtained by the relative deficiency of the test amino acid was independent of the 
Table 6 - Calculations for the digestible lysine requirements (Lys) using equation (7) for males and females in each period for the targeted response estimated for the Cobb500 genotype using data from the manual for the strain (Cobb, 2012).

\begin{tabular}{|c|c|c|c|c|}
\hline \multicolumn{5}{|l|}{ Period I (6-21 days) } \\
\hline & \multicolumn{2}{|c|}{ Males } & \multicolumn{2}{|c|}{ Females } \\
\hline $\mathrm{NR}^{1}\left(\mathrm{mg}\right.$ BW0.67 $\mathrm{kg}^{-1}$ day $\left.^{-1}\right)$ & \multicolumn{2}{|c|}{2578} & \multicolumn{2}{|c|}{2499} \\
\hline Efficiency $\left(b c^{-1}\right)$ & \multicolumn{2}{|c|}{0.000058} & \multicolumn{2}{|c|}{0.000062} \\
\hline Lys (mg BW $0.67 \mathrm{~kg}^{-1}$ day $^{-1}$ ) & \multicolumn{2}{|c|}{1131} & \multicolumn{2}{|c|}{1058} \\
\hline \multirow[t]{7}{*}{ Lys (mg day-1) } & \multicolumn{2}{|c|}{581} & \multicolumn{2}{|l|}{512} \\
\hline & \multicolumn{4}{|c|}{ Optimum level of dietary lysine $\left(\mathrm{g} \mathrm{kg}^{-1}\right)$} \\
\hline & Feed intake ${ }^{2}$ & Lys & Feed intake ${ }^{2}$ & Lys \\
\hline & $\mathrm{g} \mathrm{day}^{-1}$ & $\mathrm{~g} \mathrm{~kg}^{-1}$ & g day $^{-1}$ & $\mathrm{~g} \mathrm{~kg}^{-1}$ \\
\hline & 55 & 10.6 & 55 & 9.3 \\
\hline & 65 & 8.9 & 65 & 7.9 \\
\hline & 75 & 7.7 & 75 & 6.8 \\
\hline \multicolumn{5}{|l|}{ Period II (22-37 days) } \\
\hline & \multicolumn{2}{|c|}{ Males } & \multicolumn{2}{|c|}{ Females } \\
\hline NR (mg BW0.67 kg-1 day ${ }^{-1}$ ) & \multicolumn{2}{|c|}{2449} & \multicolumn{2}{|c|}{2354} \\
\hline Efficiency $\left(b c^{-1}\right)$ & \multicolumn{2}{|c|}{0.000066} & \multicolumn{2}{|c|}{0.000071} \\
\hline Lys (mg BW $0.67 \mathrm{~kg}^{-1}$ day $^{-1}$ ) & \multicolumn{2}{|c|}{1205} & \multicolumn{2}{|c|}{1090} \\
\hline \multirow[t]{7}{*}{ Lys (mg day $\left.{ }^{-1}\right)$} & \multicolumn{2}{|c|}{1538} & \multicolumn{2}{|l|}{1340} \\
\hline & \multicolumn{4}{|c|}{ Optimum level of dietary lysine $\left(\mathrm{g} \mathrm{kg}^{-1}\right)$} \\
\hline & Feed intake ${ }^{2}$ & Lys & Feed intake ${ }^{2}$ & Lys \\
\hline & $\mathrm{g} \mathrm{day}^{-1}$ & $\mathrm{~g} \mathrm{~kg}^{-1}$ & $\mathrm{~g}$ day $^{-1}$ & $\mathrm{~g} \mathrm{~kg}^{-1}$ \\
\hline & 163 & 9.4 & 138 & 9.7 \\
\hline & 173 & 8.9 & 148 & 9.1 \\
\hline & 183 & 8.4 & 158 & 8.5 \\
\hline \multicolumn{5}{|l|}{ Period III (38-53 days) } \\
\hline & \multicolumn{2}{|c|}{ Males } & \multicolumn{2}{|c|}{ Females } \\
\hline NR (mg BW ${ }^{0.67} \mathrm{~kg}^{-1}$ day $^{-1}$ ) & 195 & & 1809 & \\
\hline Efficiency $\left(b c^{-1}\right)$ & 0.000 & & 0.0001 & \\
\hline Lys (mg BW0.67 $\mathrm{kg}^{-1}$ day $^{-1}$ ) & 101 & & 910 & \\
\hline Lys (mg day-1) & 217 & & 1674 & \\
\hline & Optimum & evel of di & tary lysine (g k & $\left.g^{-1}\right)$ \\
\hline & Feed intake ${ }^{2}$ & Lys & Feed intake ${ }^{2}$ & Lys \\
\hline & $\mathrm{g}_{\text {day }}{ }^{-1}$ & $\mathrm{~g} \mathrm{~kg}^{-1}$ & $\mathrm{~g} \mathrm{day}^{-1}$ & $\mathrm{~g} \mathrm{~kg}^{-1}$ \\
\hline & 225 & 9.6 & 188 & 8.9 \\
\hline & 235 & 9.2 & 198 & 8.5 \\
\hline & 245 & 8.9 & 208 & 8.1 \\
\hline
\end{tabular}

${ }^{1}$ From Table 5: $65 \%$ of the $\mathrm{NR}_{\mathrm{m}} \mathrm{T}\left(3,966\right.$ and 3,845 mg BW0.67 $\mathrm{kg}^{-1}$ day ${ }^{-1}$ for males and females, respectively) in period I for both sexes; $72 \%$ of the $\mathrm{NR}_{\max } \mathrm{T}$ for males $\left(3,401 \mathrm{mg} \mathrm{BW}^{0.67} \mathrm{~kg}^{-1}\right.$ day $\left.^{-1}\right)$ and $71 \%$ of the NR ${ }_{\max } T$ for females (3,315 mg BW0.67 $\mathrm{kg}^{-1}$ day $\left.^{-1}\right)$ in period II; $79 \%$ of the NR $\mathrm{T}$ for males $(2,479$ $\mathrm{mg} \mathrm{BW} \mathrm{W}^{0.67} \mathrm{~kg}^{-1}$ day $\left.^{-1}\right)$ and $78 \%$ of the $\mathrm{NR}_{\max } \mathrm{T}^{\mathrm{T}}$ for females $\left(2,319 \mathrm{mg}\right.$ BW ${ }^{0.67}$ $\mathrm{kg}^{-1}$ day $^{-1}$ ) in period III; ${ }^{2}$ daily feed intake was based on the mean values for the given period in the management guide for the strain (Cobb, 2012) with extrapolation for $10 \mathrm{~g}$ above and $10 \mathrm{~g}$ below the mean.

level of dietary protein and was not influenced by the effects of dilution (Fisher and Morris, 1970).

The NMR value estimated in this study represents the amount of $\mathrm{N}$ that needs to be ingested to compensate for endogenous nitrogen losses, according to Samadi and Liebert (2006). The procedure used in this study is an alternative approach for estimating the maintenance requirements for nitrogen and amino acids because the values obtained from the traditional method, which uses the inevitable losses from the body protein in birds fed nitrogen-free diets, are underestimated (Samadi and Liebert, 2006). As an example of this, the total loss of endogenous nitrogen by growing broilers, estimated at 180 mg BW ${ }^{0.75} \mathrm{~kg}^{-1}$ day $^{-1}$ by Leeson and Summers (2001), is far below the values determined in this study when they are expressed in $\mathrm{BW}^{0.75}$ (approximately $28 \%$ for both males and females).

The procedure adopted here assumes that endogenous catabolism is largely or completely suppressed when the animal is receiving protein in the feed (Mitchel, 1924). The proportion of the maintenance requirement in relation to the total requirement increases with the age of the bird, and this element must be factored into the estimates. The NMR values obtained in this study are in accordance with the values estimated by Samadi and Liebert (2007) of 220, 260 and $273 \mathrm{mg} \mathrm{BW}^{0.67}$ $\mathrm{kg}^{-1}$ day $^{-1}$ for males and 223, 275 and $264 \mathrm{mg} \mathrm{BW}^{0.67} \mathrm{~kg}^{-1}$ day $^{-1}$ for females during periods I (10-25 days), II (30-45 days) and III (50-65 days), respectively.

As the maintenance requirements of the broilers become a larger proportion of the total requirement with increasing age, the nitrogen requirements to maximize protein deposition decrease. Due to differences among animals in their maintenance requirements and growth potentials, the response of the study population was curvilinear. In a curvilinear response, the utilization of a nutrient is characterized by (i) a linear phase at a suboptimal level, (ii) a curvilinear stage, and (iii) a decrease to the point at which the maximum response is obtained (Baker, 1986). In the curvilinear response obtained in this study (Figure 2), the $\mathrm{ND}_{\max } \mathrm{T}$ represents the physiological limit of nitrogen deposition that is specific to the genotype.

The threshold values $\left(\mathrm{ND}_{\max } \mathrm{T}\right)$ observed decreased as age increased and were close to the results reported in the studies of Samadi and Liebert, (2007) for males $(3,746 \mathrm{mg}$ vs. $3,676 \mathrm{mg}$ in age period I; $3,137 \mathrm{mg}$ vs. $2,843 \mathrm{mg}$ in age period II; $2,204 \mathrm{mg}$ vs. $1,864 \mathrm{mg}$ in age period III) and females $(3,620 \mathrm{mg}$ vs. $3,582 \mathrm{mg}$ in age period I; 3,038 $\mathrm{mg}$ vs. $2,697 \mathrm{mg}$ in age period II; 2,048 $\mathrm{mg}$ vs. $1,708 \mathrm{mg}$ in age period III) fed diets that were first limiting in lysine.

The results from the simulation data (Table 5) indicate that there is still a capacity for retention that could be exploited by geneticists and nutritionists because the potentials for nitrogen retention currently represent only 65,72 , and $79 \%$ (average value of $72 \%$ ) of the $\mathrm{NR}_{\max } \mathrm{T}$ for males and 65,71 , and $78 \%$ (average value of $71 \%$ ) of the $\mathrm{NR}_{\max } \mathrm{T}$ for females during periods I, II, and III, respectively.

The differences in the potentials from 2008 to 2012 calculated from the simulation indicated a slight increase of approximately 1-4\% for males but no more than $1 \%$ for females, a result of genetic improvements of this genotype over the last four years. Therefore, these differences can also be attributed to the fact that the growth curve describes the deposition under standard 
feeding conditions in which the physiological limit is not expressed.

The characterization of the growth patterns of this strain for protein deposition and the efficiency of utilization allows us to establish the appropriate levels for protein and amino acids to reach the desired potential tailored to the limiting conditions. Using the model parameters and the data obtained in this study, it is possible to establish an optimal lysine intake based on the targeted nitrogen retention (as a \% age of the $\mathrm{NR}_{\max } \mathrm{T}$ ) estimated from the actual Cobb500 recommendation (Table 6). The simulation indicated that to meet $65 \%$ of the $\mathrm{NR}_{\max } \mathrm{T}$ (period I), the concentration of digestible Lys in the diet should be $10.6 \mathrm{~g} \mathrm{~kg}^{-1}$ for males and $9.3 \mathrm{~g} \mathrm{~kg}^{-1}$ for females to obtain values close to the recommendations from the literature if a daily feed intake of 10 grams less than the recommended (Cobb, 2012) is considered. This recommendation is similar to that made by Goulart et al. (2008) of $10.6 \mathrm{~g} \mathrm{~kg}^{-1}\left(580 \mathrm{mg} \mathrm{day}{ }^{-1}\right)$ for the initial 8-21 days phase for males.

Zaghari et al. (2002) reported that the digestible Lys requirement for maximum body weight gain from 6-21 days of age was 10.75 and $10.49 \mathrm{~g} \mathrm{~kg}^{-1}$ for males and females, respectively. The recommendation for females by these authors is higher than the recommendation in this study, but for males, the recommendations are very consistent. Han and Baker (1994) obtained a digestible lysine requirement estimate of $10.7 \mathrm{~g} \mathrm{~kg}^{-1}$ for males, and this recommendation is also similar. The values from these authors for maximum body weight gain can be compared to the estimated digestible lysine recommendation in this study due to the direct relationship between the Lys concentration in the diet and the increase in body weight and protein deposition (Mahdavi et al., 2012).

To meet $71 \%$ of the $\mathrm{NR}_{\max } \mathrm{T}$ for males and $72 \%$ of the $\mathrm{NR}_{\max } \mathrm{T}$ for females in period II, the concentration of digestible Lys in the diet should be $9.4 \mathrm{~g} \mathrm{~kg}^{-1}$ for males and $9.7 \mathrm{~g} \mathrm{~kg}^{-1}$ for females to obtain values close to the recommendations from the literature if a daily feed intake of 10 grams less than recommended (Cobb, 2012) for these periods is considered (Table 6). These values are close to the recommendations of Han and Baker (1994) of $9.9 \mathrm{~g} \mathrm{~kg}^{-1}$ for males and $9.1 \mathrm{~g} \mathrm{~kg}^{-1}$ for females to maximize weight gain during 3 to 6 wks of age. Similar recommendations for male broilers were made by Goulart et al. (2008) of $9.98 \mathrm{~g} \mathrm{~kg}^{-1}$ for the growth (22-42 d) phase to obtain the maximal performance. The estimated digestible lysine requirements in this study for periods I and II corresponded to approximately $93 \%$ of the recommendations in the Brazilian Tables of $11.5 \mathrm{~g}$ $\mathrm{kg}^{-1}\left(10.7 \mathrm{~g} \mathrm{~kg}^{-1}\right)$ and $10.1 \mathrm{~g} \mathrm{~kg}^{-1}\left(9.4 \mathrm{~g} \mathrm{~kg}^{-1}\right)$ of digestible lysine at ages 8 to 21 days and 30 to 42 days for male broilers, respectively.

To meet $79 \%$ of the $\mathrm{NR}_{\max } \mathrm{T}$ for males and $78 \%$ of the $\mathrm{NR}_{\max } \mathrm{T}$ for females in period III, the concentration of digestible Lys in the diet should be $9.2 \mathrm{~g} \mathrm{~kg}^{-1}$ for males and $8.5 \mathrm{~g} \mathrm{~kg}^{-1}$ for females if the mean daily feed intake recommended for this period is considered (Table 6). Mahdavi et al. (2012) determined that the digestible Lys requirement for maximum body weight was $9.3 \mathrm{~g}$ $\mathrm{kg}^{-1}$ for both males and females for broilers between 35 and 49 days of age. Compared with the recommendation in this study, the estimate for males is very close, but that for females is higher. However, Mahdavi et al. (2012) concluded that high-yield broilers should be fed a minimum of $8.5 \mathrm{~g} \mathrm{~kg}^{-1}$ digestible Lys from 35 to 49 days of age, and this value is similar to the estimate made for female Cobb 500 broilers in this study.

The digestible lysine requirements estimated in this study are slightly below the calculations for $60 \%$ of the theoretical potential for nitrogen retention (10-25 days: $11.0 \mathrm{~g} \mathrm{~kg}^{-1}$ lysine, $60 \mathrm{~g}$ daily feed intake; $30-45$ days: $10.3 \mathrm{~g} \mathrm{~kg}^{-1}$ lysine, $140 \mathrm{~g}$ daily feed intake; $50-65$ days: $9.6 \mathrm{~g} \mathrm{~kg}^{-1}$ lysine, $170 \mathrm{~g}$ daily feed intake) used in the study by Samadi and Liebert (2007) for the Cobb500 genotype. Urdanneta-Rincon et al. (2005) reported that both protein synthesis and breakdown increased when the levels of dietary Lys and crude protein were above those required for maximum growth. In this way, using the maximum potential for deposition as a reference for modeling the digestible lysine requirement allows for optimal digestible Lys levels to be supplied, resulting in a decrease in nitrogen excretion and a reduction in the feed costs, because protein is an expensive nutrient.

\section{Conclusion}

The model used to describe the maximum potential for $\mathrm{N}$ deposition in birds allows for estimates of the digestible lysine requirements in the diet. The flexibility of the model enables the requirements to be modeled while considering the potential for deposition and the feed intake of the birds within the range of practical performance data. The digestible lysine requirements were estimated at 10.6, 9.4, and $9.2 \mathrm{~g} \mathrm{~kg}^{-1}$ for males and 9.3, 9.7, and $8.5 \mathrm{~g} \mathrm{~kg}^{-1}$ for females during 6-21 days (period I), 22-37 days (period II), and 38-53 days (period III), respectively.

\section{Acknowledgements}

The authors gratefully acknowledge the São Paulo Research Foundation (FAPESP) for the financial support, Ajinomoto Ltd. for the amino acid analysis and the researchers of Georg-August University of Goettingen (Germany) for their contributions to this study.

\section{References}

Association of Official Analytical Chemists [AOAC]. 2005. Official Methods of Analysis. 18ed. AOAC, Gaithersburg, MD, USA.

Baker, D.H. 1986. Problems and pitfalls in animal experiments designed to establish dietary requirements for essential nutrients. Journal of Nutrition 116: 2339-2349. 
Emmert, J.L.; Baker, D.H. 1997. Use of the ideal protein concept for precision formulation of amino acid levels in broiler diets. The Journal of Applied Poultry Research 6: 462-470.

Cobb Vantress. 2008. Cobb Broiler Management Guide. CobbVantress, Siloam Springs, AR, USA.

Cobb Vantress. 2012. Cobb Broiler Management Guide. CobbVantress, Siloam Springs, AR, USA.

Curnow, R.N. 1973. A smooth population response curve based on an abrupt threshold and plateau model for individuals. Biometrics 29: 1-10.

Fisher, C.; Morris, T.R. 1970. The determination of the methionine requirement of laying pullets by a diet dilution technique. British Poultry Science 11: 67-82.

Goulart, C.C.; Costa, F.G.P.; Neto, R.C.L.; Souza, J.G.; Silva, J.H.V.; Givisiez, P.E.N. 2008. Digestible lysine requirements for male broilers from 1 to 42 days old. Revista Brasileira de Zootecnia 37: 876-882 (in Portuguese, with abstract in English).

Han, Y.; Baker, D.H. 1994. Digestible lysine requirement of male and female broiler chicks during the period three to six weeks posthatching. Poultry Science 73: 1739-1745.

Leeson, S.; Summers, J.D. 2001. Nutrition of the Chicken. 4ed. University Books, Guelph, Canadá.

Mahdavi, A.; Shivazad, M.; Alemi, F.; Zaghari, M.; Moravej, H.; Darabighane, B. 2012. Digestible lysine requirement of broilers based on practical diet. Italian Journal of Animal Science 11: e13.

Mitchel, H.H. 1924. A method of determining the biological value of protein. The Journal of Biological Chemistry 58: 873-903.

Rosa, A.P.; Pesti, G.M.; Edwards Jr, H.M.; Bakalli, R. 2001. Tryptophan requirements of different broiler genotypes. Poultry Science 80: 1718-1722.

Rostagno, H.S.; Albino, L.F.T.; Donzele, J.L.; Gomes, P.C.; Oliveira, R.F.; Lopes, D.C.; Ferreira, A.S.; Barreto, S.L.T.; Euclides, R.F. 2011. Brazilian Tables for Poultry and Swine: Composition of Feedstuffs and Nutritional Requirements = Tabelas Brasileiras para Aves e Suínos: Composição de Alimentos e Exigências Nutricionais. 3ed. Editora UFV, Viçosa, MG, Brazil (in Portuguese).
Samadi, F; Liebert, F. 2006. Estimation of nitrogen maintenance requirements and potential for nitrogen deposition in fastgrowing chickens depending on age and sex. Poultry Science 85: $1421-1429$.

Samadi, F.; Liebert, F. 2007. Lysine requirement of fast growing chickens : effects of age, sex, level of protein deposition and dietary lysine efficiency. The Journal of Poultry Science 44: 6372.

Samadi, F; Liebert, F. 2008. Modelling the optimal lysine to threonine ratio in growing chickens depending on age and efficiency of dietary amino acid utilizasation. British Poultry Science 49: 45-54.

Smith, E.R.; Pesti, G.M. 1998. Influence of broiler strain cross and dietary protein on the performance of broilers. Poultry Science 77: 276-281.

Urdanneta-Rincon, M.; Lang, K. ; Pena-Ortega, L.; Leeson, S. 2005. Lysine requirements of young broiler chickens are affected by level of dietary crude protein. Canadian Journal of Animal Science 85: 195-204.

Zaghari, M.; Shivazad, M.; Kamyab, A.; Nikkhah, A. 2002. Digestible lysine requirement of arian male and female broiler chicks during the 6-21 days of age. Journal of Agricultural Science and Technology 4: 111-117.

Zuprizal; Larbier, M.; Chagneau, A.M. 1992. Effect of age and sex on the true digestibility of amino acids of rapeseed and soybean meals in growing broilers. Poultry Science 7: 1486-1492. 